\title{
Dealing with Urbanization in South Asia: Learning from Urban Spatial Configurations within Small TWCs
}

\author{
Locana Gunaratna \\ Architect/Planner and Fellow, National Academy of Sciences Sri Lanka.
}

gunaratnaassociates@gmail.com

\begin{abstract}
There is a considered view that dealing with urbanization and its adverse impacts in South Asia has been ineffectual due to too great a reliance upon exogenous theory developed for different socio-economic circumstances. This paper expands on one of the theories that underpins the desired new theoretical base relating to some phenomena in their observable presence in many Third World Countries (TWCs). The spatial distortion that this phenomena represents in the city systems of these countries, particularly 'urban primacy', is directly attributable to the prolonged imposition of colonial economies on these countries. The obvious question that arises concerns the relevance of these deformed city systems to the post-colonial economies and social objectives pursued in these countries, especially if they are differently oriented from those of the colonial era. The study is based upon urban statistics gathered from eight TWCs selected from three continents.
\end{abstract}

\section{Introduction}

The view has already been published that the major efforts to deal with urbanization in South Asia have relied generally upon exogenous theory and practice developed more than a century ago for very different socio-economic circumstances (Gunaratna, 2014). In that publication, the case has also been made citing key intellectual sources, to build a relevant theoretical base for a new approach to deal with urbanization in South Asia. It would be appropriate here to quote two paragraphs from that publication: 'Many planners grappling with urbanization issues in the TWCs do not confront the subject directly and in its entirety. They focus their attention only on its resultant urban impacts which are within the affected cities themselves. Some of the typical theoretical writings which support such limited actions may indeed be valuable contributions to the on-going urban planning discourse, but not necessarily to the broader concerns relating to urbanization. These writings tend to lay stress upon the urgent need for "radical planning" to support participation by often large, disenfranchised segments of urban and urbanizing populations. This focus was seen, for example, in the discussions: on squatter settlements in Latin America (Turner and Fichter, 1972); more recently on anti-eviction campaigns within the Western Cape in South Africa (Miraftab, 2009); and, still more recently on the "stubborn realities" of informal settlements in the global south (Watson, 2012). Even when dealing directly with urbanization, reliance is invariably placed on intra-urban interventions through the various professional disciplines concerned with urban planning. The solutions are consequently and inevitably based upon guiding the expansion of impacted cities in one way or other, often involving the planning and building of satellite towns in the vicinity of those cities. The predominant intellectual material which underpins the attempts to manage urbanization in this particular manner originated in the West a century ago.

'The fact however is that rural out-migration impacts not only on cities that receive the migrants but also upon the rural hinterlands they left behind. It does so quite adversely in that agriculture is increasingly deprived of manpower and thus subject to continuing neglect. There are also studies which strive to predict the consequences of horizontal urban expansions due to rapid urbanization and their likely spatial impact on rural land. The main prediction in one such recent study which was based on the assumption of continuing current 
trends, suggests the tripling of urban land cover worldwide within the next three decades with a notably adverse impact upon biodiversity (Seto et al, 2012). That study also brought to light that the main biodiversity 'hotspots' likely to be affected by these trends are in theThird World with many being in South Asia.' (Gunaratna, 2014)

This present paper focuses and expands on one of the theories considered as being of fundamental relevance to the desired new approach. It has to do with the phenomena of 'urban primacy' in its observable presence especially in the smaller Third World Countries (TWCs). These are countries that have all undergone colonial subjugation. It may be recalled that a few scholars had sought to understand whether a relationship exists between the rank and size of cities within a national urban system. Their studies suggested the existence of two very distinct patterns. In one, rank and size are correlated in a regular and predictable manner, wherein the rank-size rule is said to apply. The other is one in which the largest city predominates very substantially over the next in rank and all other cities. Such a pattern is said to display 'primacy' and the first ranking city is called a 'primate city'.

Observations on the rank-size relationship was written about first by Jefferson (1936) and written upon further more than a decade later by Zipf (1949). More on the subject has also been written by Linsky (1965) and Nitsch (2005). Linsky (1965: 506-513) systematically pursued Jefferson's work that had been done three decades earlier. He surmised that the condition of 'primacy' is characteristic especially of smaller "underdeveloped" countries in a transitional phase of social and economic development, having a colonial past, agricultural economies, low per capita incomes, high rates of population growth and being dependent upon exports. As already mentioned, 'primacy' is not generally found in countries that have not been subjected to colonialism. Where it is found in such countries, it is much less pronounced and often due to the industrialization of agricultural activities and the consequent rural-urban migrations that have taken place in search of off-farm urban employment. The obvious question that arises about Primacy in the smaller TWCs is about the relevance of these distorted city systems to the needs of their respective post-colonial economic and social development objectives, especially if they are now being very differently poised, oriented and pursued.

An important intention here in this paper is to examine the validity of Linsky's theoretical position noting that his conclusions were based on data only from one particular year, namely 1955 . Thus this present paper explores the theory in the current context after the lapse of more than half a century. For this purpose eight countries were selected as Case Studies corresponding to Linsky's stated criteria, from among the TWCs geographically located in the continents of Asia, Sub-Saharan Africa and South America. Of the TWCs, India, South Africa, Brazil and Argentina were excluded from the examination on the grounds that they were too large to conform to the size specification in the theory. The countries wherein their boundaries had been altered substantially in the post-colonial period were also excluded in the process of selection. Thus the sample of TWCs was a random selection from among those small, predominantly agrarian coastal countries in the three continents of Asia, Africa and South America. The countries selected were: Vietnam, Myanmar, Sri Lanka from Asia; Mozambique, Senegal and Ghana from Africa; and, Chile and Peru from South America. It will be seen that care has been taken in this selection to also consider the impact of as many as possible of the main European colonizing countries these latter countries being France, Britain, Portugal and Spain. 


\begin{tabular}{|c|l|r|}
\hline \multicolumn{3}{|c|}{ CITY POPULATIONS IN VIETNAM (2013) } \\
\hline Rank & \multicolumn{1}{|c|}{ City } & \multicolumn{1}{|c|}{ Population (est) } \\
\hline 1 & Ho Chi Mihn City & $3,467,331$ \\
\hline 2 & Hanoi & $1,431,270$ \\
\hline 3 & Da Nang & 752,493 \\
\hline 4 & Haiphong & 602,695 \\
\hline 5 & Bien Hoa & 407,208 \\
\hline 6 & Hue & 287,217 \\
\hline 7 & Nha Trang & 283,441 \\
\hline 8 & Can Tho & 259,598 \\
\hline 9 & Rach Gia & 228,356 \\
\hline 10 & Qui Nhon & 210,338 \\
\hline Source: & www.worldpopulationreview.com & \\
\hline & \multicolumn{2}{|c|}{} \\
\end{tabular}

Table: City Populations in Vietnam, 2013

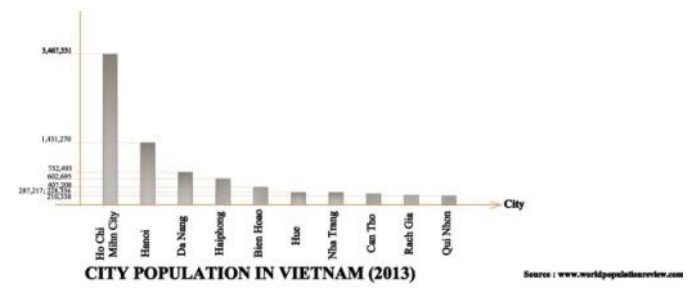

Figure: City Populations in Vietnam, 2013

\section{Mynmar}

British fought three wars between 1824 and 1885 to gain control of Mynmar (then called

\begin{tabular}{|c|l|r|}
\hline \multicolumn{2}{|c|}{ CITY POPULATIONS IN MYANMAR (2012) } \\
\hline Rank & \multicolumn{1}{|c|}{ City } & \multicolumn{1}{c|}{ Population } \\
\hline 1 & Rangoon & $4,948,920$ \\
\hline 2 & Mandalay & $1,620,758$ \\
\hline 3 & Mawlamyine & 542,017 \\
\hline 4 & Bago & 278,622 \\
\hline 5 & Pathein & 277,382 \\
\hline 6 & Meiktila & 244,768 \\
\hline 7 & Mergui & 215,636 \\
\hline 8 & Akyab & 205,059 \\
\hline 9 & Myingyan & 195,675 \\
\hline 10 & Monywa & 194,532 \\
\hline Source: & Google Earth \\
\cline { 1 - 1 } & \multicolumn{2}{|c|}{} \\
\cline { 1 - 2 } &
\end{tabular}

Burma). Until 1937, Burma was ruled by the British as part of British-India with Rangoon as the capital city. British colonial rule continued thereafter under a new constitution which was by no means acceptable to the indigenous population. Many Burmese leaders did not support the British even during World War II and some including their national hero Aung San fled to receive military training in Japan. The chaotic and violent period that ensued calmed temporarily only after the war immediately after the Aung San-Atlee Agreement of 1947. The 'Union of Burma' was then established but soon thereafter General Aung San along with many of his Cabinet colleagues were assassinated. The reigns of the government were taken then over by U.Nu who was the most senior remaining member of the original Aung San Cabinet. U.Nu was ousted from power by the military led by General Ne Win in the late $1950 \mathrm{~s}$ and the military dominance in government has continued to date.

Agriculture by peasant farm families for food self-sufficiency formed the basis of the traditional Burmese economy. The main food crop was rice. The colonial impact led to trade based on the export of rice and teak and the import of manufactured goods mainly from Britain. Rangoon, the capital, at the mouth of the Irrawaddy River was used as the main port for shipping and trade. The benefits of this colonial trade economy did not accrue to the Burmese as much as it did to the British and Indian merchants and money lenders. This led to a more closed economy during several decades of the post-colonial period which tended to exclude foreign businesses from participating in the Burmese economy. (British rule in Burma; Wikipedia)

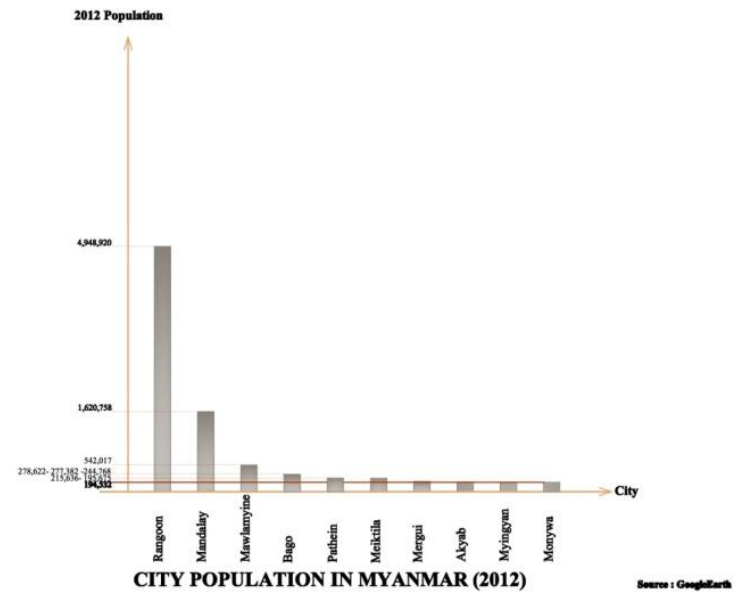

Figure: City Populations in Myanmar, 2012 


\section{Sri Lanka}

European colonial influence in Sri Lanka began in 1505 with the arrival of the Portuguese, continued through a period of Dutch occupation starting in 1656 till the early 18th Century when British control ensued and extended till 1948. The Portuguese and the Dutch controlled in turn only the maritime regions with the bulk of the island being firmly controlled and militarily defended from the hill country by the Sinhalese. The British gained control of the hill country through a treaty and thus claimed maintained jurisdiction over the entire island. Both the Portuguese and the Dutch were keenly interested in the spice trade. Thus the imposed colonial economy involved the cultivation and extraction of spice with a special focus on cinnamon, all of which was for export mainly to Europe. The main port through which this trade traversed was through Colombo where a fort had been constructed by the Portuguese and improved upon by the Dutch. The British were more interested agricultural produce which could be had from the fertile hills which soon were covered with plantations of coffee, tea and later, rubber and coconut. New transport routes and towns were developed between these plantations and Colombo generally to the exclusion of other areas. With industrialization in Britain, railroads were built to supplement the transportation infrastructure for the extraction and delivery of plantation produce to the port in Colombo for shipment to Britain. The port was substantially improved to cope with this trade to the extent that it was ranked at the end of

\begin{tabular}{|c|l|r|}
\hline \multicolumn{3}{|c|}{ CITY POPULATIONS IN SRI LANKA) } \\
\hline Rank & \multicolumn{1}{|c|}{ City } & \multicolumn{1}{|c|}{ Population } \\
\hline 1 & $\begin{array}{l}\text { Colombo (with suburbs: Dehiwela, } \\
\text { Mt. Lavinia, Moratuwa and Peliyagoda) }\end{array}$ & $1,238,029$ \\
\hline 2 & Negombo \& Katunayake & 204,570 \\
\hline 3 & Sri Jayawardenepura Kotte & 135,806 \\
\hline 4 & Kandy & 125,351 \\
\hline 5 & Kalmunai & 106,783 \\
\hline 6 & Vavuniya & 99,653 \\
\hline 7 & Galle & 99,478 \\
\hline 8 & Trincomalee & 99,135 \\
\hline 9 & Batticaloa & 92,332 \\
\hline 10 & Jaffna & 88,138 \\
\hline Source: & Wikepedia (Conurbation; 2012 estimates) \\
\cline { 1 - 3 } & &
\end{tabular}

WW1 to be the 3rd best in the British Empire and 5th worldwide.

\section{Mozambique}

Trade with the outside world had taken place in the region of Mozambique through Arab trade settlements on the coast till the Portuguese arrived in 1498 and gradually took over that trade. Portuguese trading posts and

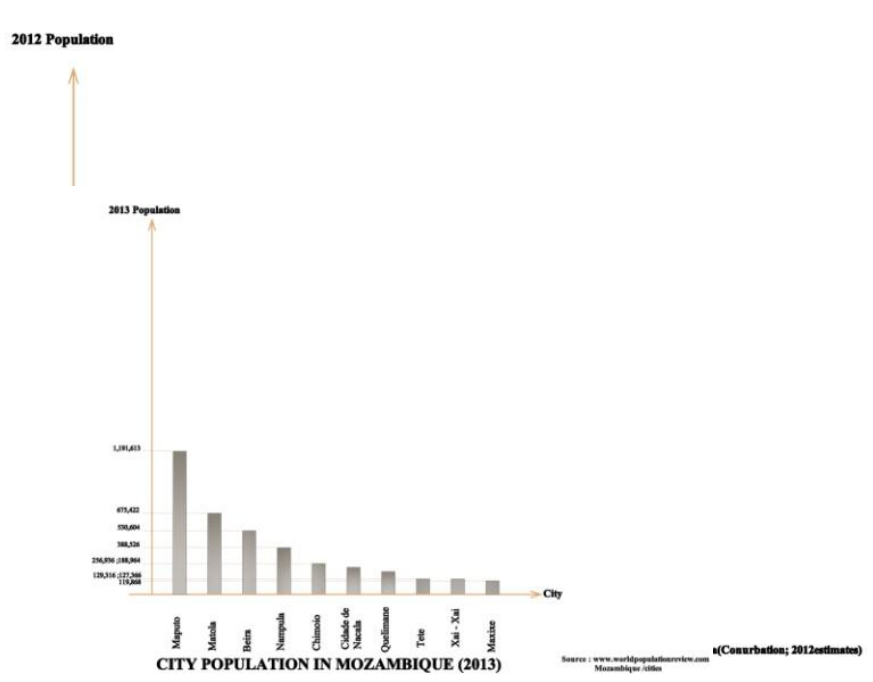

ports were established and began to control trade beginning about 1500. The Portuguese government based in Lisbonhad greater interest in their colonized territories in the East and the West. Thus, their control in Mozambique was exercised through delegated powers to Portuguese settlers and private companies financed mostly by the British. By the 20th Century, railroad lines had been established mainly to ship local labour to British colonies nearby and to South Africa.

Even after World War II, Portugal attempted to hold on to whatever colonial possessions they had. With the economy of Mozambique continuing to benefit mainly the white settlers, anti-colonial political groups formed and coalesced into a liberation front ('FRELIMO') in 1962. An armed struggle ensued in 1964 which lasted 10 years and led to a negotiated 'independence' for Mozambique in 1975. (https://en.wikipedia.org/wiki/History_of_Mo zambique) 


\begin{tabular}{|c|l|r|}
\hline \multicolumn{2}{|c|}{ CITY POPULATIONS IN MOZAMBIQUE (2013) } \\
\hline Rank & \multicolumn{1}{|c|}{ City } & \multicolumn{1}{c|}{ Population } \\
\hline 1 & Maputo & $1,191,613$ \\
\hline 2 & Matola & 675,422 \\
\hline 3 & Beira & 530,604 \\
\hline 4 & Nampula & 388,526 \\
\hline 5 & Chimoio & 256,936 \\
\hline 6 & Cidade de Nacala & 224,795 \\
\hline 7 & Quelimane & 188,964 \\
\hline 8 & Tete & 129,316 \\
\hline 9 & Xai-Xai & 127,366 \\
\hline 10 & Maxixe & 119,868 \\
\hline Source: & $\begin{array}{l}\text { Www.worldpopulationreview.com/ } \\
\text { Mozambique /cities }\end{array}$ \\
\cline { 2 - 3 } & \multicolumn{2}{|c}{} \\
\cline { 2 - 3 } &
\end{tabular}

Figure: City Populations in Mozambique, 2013

\section{Senegal}

Despite competition from several other European trade interests, France came into possession in 1677 of the small island of Goree very near Dakar the capital city of Senegal. This was an important departure point in the ongoing slave trade at that time. French extension into the mainland of Senegal took place in 1850 displacing the indigenous kingdoms. There was a merger in 1959 between Senegal and French Sudan to form the Republic of Mali which broke-up within a year. Independence from France was proclaimed by Senegal and a Senagalese became their first president in 1960.

The colonial economy of Senegal was based on agriculture with particular attention to the growing, transport to the port/capital city and the export of peanuts. Since independence there was some diversification but state control of the purchase of all agricultural products and the growth of a 'rentier class' are said to have led to the growers receiving less than the products' worth. This had resulted in the exacerbation of rural-urban migration.

Source: www.nationsencyclopedia.com

\begin{tabular}{|c|l|r|}
\hline \multicolumn{2}{|c|}{ CITY POPULATIONS IN SENEGAL (2010) } \\
\hline Rank & \multicolumn{1}{|c|}{ City } & \multicolumn{1}{c|}{ Population } \\
\hline 1 & Dakar & $2,396,800$ \\
\hline 2 & Touba Mosquee & 620,500 \\
\hline 3 & Thies & 278,200 \\
\hline 4 & Mbour & 199,400 \\
\hline 5 & Kaolack & 193,400 \\
\hline 6 & Saint-Louis & 180,900 \\
\hline 7 & Rufisque & 173,100 \\
\hline 8 & Ziguinchor & 165,100 \\
\hline 9 & Diourbel & 102,800 \\
\hline 10 & Louga & 88,300 \\
\hline Source: & $\begin{array}{l}\text { Agence Nationale de la Statistique et de } \\
\text { la Demographic, Senegal (web) 2010 }\end{array}$ & \multicolumn{1}{|c|}{} \\
\cline { 1 - 3 } & \multicolumn{2}{|c|}{} \\
\cline { 1 - 3 } &
\end{tabular}

Figure: City Populations in Senegal, 2013

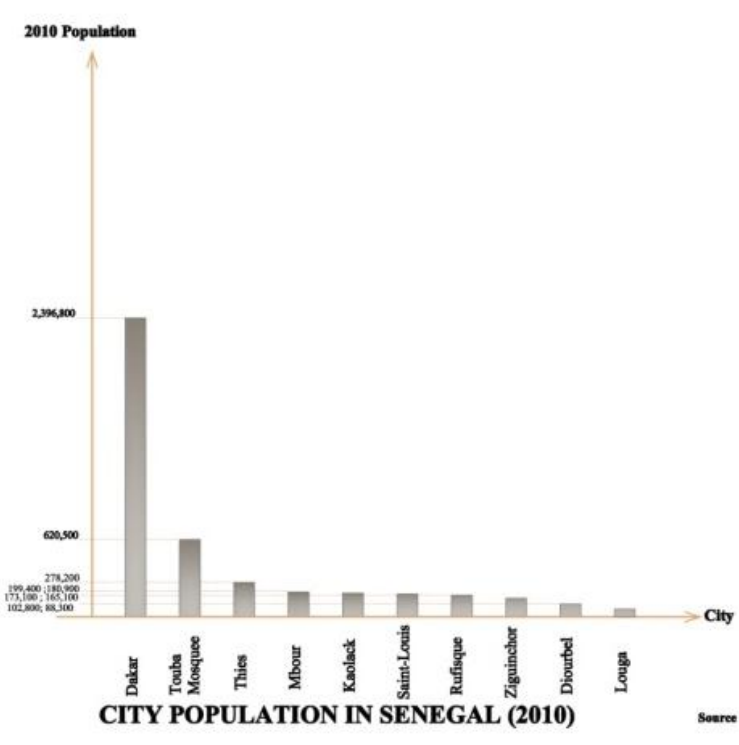

\section{Ghana}

Accra on the West African coast became prominent in the 18th century due to nearby Dutch forts and their active participation in the slave trade. Following the abolition of that trade in the early 19th century the Dutch sold their forts to the British. After many battles with the indigenous peoples of central Ghana and the virtual destruction of Kumasi the Ashanti capital, Ghana was declared a Crown colony of Britain. Accra was selected by them as Ghana's capital city. In 1908 the railway was built connecting Kumasi with Accra. Its completion in 1923 established a strong connection between the cocoa growing areas with the port in Accra. Cocoa soon became 
Ghana's main export. Accra's prosperity and the construction of infrastructure lead to much migration from the rural areas. The Ghanaian campaign began with the Accra riots of 1948 . Independence from Britain was achieved in 1957. Adarkwa (2012)

\begin{tabular}{|c|c|c|}
\hline \multicolumn{3}{|c|}{ CITY POPULATIONS IN GHANA (2013) } \\
\hline Rank & City & Population \\
\hline 1 & Accra & $1,963,264$ \\
\hline 2 & Kumasi & $1,468,609$ \\
\hline 3 & Tamale & 360,579 \\
\hline 4 & Takoradi & 232,919 \\
\hline 5 & Achiaman & 202,932 \\
\hline 6 & Tema & 155,782 \\
\hline 7 & Teshi Old Town & 144,013 \\
\hline 8 & Cape Coast & 143,015 \\
\hline 9 & Sekondi-Takoradi & 138,872 \\
\hline 10 & Obuasi & 137,856 \\
\hline Source: & www.worldpopulationreview.com & \\
\hline
\end{tabular}

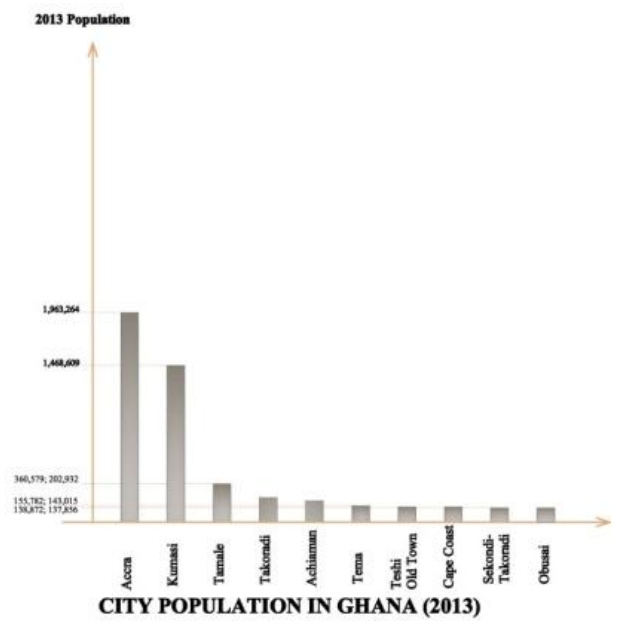

Figure: City Populations in Ghana, 2013

The lack of substantial difference in the size of the populations between the first and second ranked cities i.e. Accra and Kumasi, is uncommon in the studied TWCs and is peculiar to Ghana in comparison to other TWCs. This therefore needs some explanation. During the colonial period after the abolition of the slave trade, Kumasi became almost as important as Accra due to the fact that it was the collection centre for raw material to be exported from Accra. The construction of the railway connection between the two cities added more weight to the importance and growth of Kumasi. In the immediate postindependence development effort focused on import substitution under the leadership of Kwami Nkrumah (1957-1966), both Accra and Kumasi received almost equal importance in urban infrastructure development. The important place given to Kumasi has continued even in the subsequent development strategies to date.

\section{Chile}

The 16th century saw the Spanish conquistadors active in a long coastal strip of land in the Southwestern seaboard of the South American continent. That territory became a colony of Spain in 1540 and came to be known as Chile. The colonial economy was based on agricultural exports and later also on saltpeter and copper transported through the main port of Santiago. Independence from Spain, gained in 1818 led to an elitist controlled economy. After a period of turmoil when the country was sucked into Cold War politics, the country transitioned peacefully to democracy around 1990. (Wikipedia)

\begin{tabular}{|c|l|r|}
\hline \multicolumn{3}{|c|}{ CITY POPULATIONS IN CHILE (2013) } \\
\hline Rank & \multicolumn{1}{|c|}{ City } & Population \\
\hline 1 & Santiago & $4,837,295$ \\
\hline 2 & Puente Alto & 510,471 \\
\hline 3 & Antofagasta & 309,832 \\
\hline 4 & Vina del Mar & 294,551 \\
\hline 5 & Valparaiso & 282,448 \\
\hline 6 & Talcahuano & 252,968 \\
\hline 7 & San Bernardo & 249,858 \\
\hline 8 & Temuco & 238,129 \\
\hline 9 & Iquique & 227,499 \\
\hline 10 & Concepcion & 215,413 \\
\hline Source: & www.worldpopulationreview.com & \multicolumn{2}{|c|}{} \\
\cline { 1 - 3 } & \multicolumn{2}{|c|}{} \\
\cline { 1 - 3 } &
\end{tabular}




\section{Peru}

The availability of a large indigenous population for use as labor and the extraordinary mineral wealth of Peru were very beneficial to Spain's colonial economy. Agricultural products such as sugar, textiles and a great deal of its minerals were exported to Spain and to Europe through Lima, Peru's capital and port. Despite high growth, the War of the Spanish Succession (1701-1714) was eventually followed by economic stagnation and the marginalization of the indigenous peoples of Peru. (Mahoney, 52, 66, 80, 86); (Wikipedia)

The War of the Pacific (1879-1888) which involved Peru, Bolivia and Chile left its toll on Peru. Despite an effort to rebuild and introduce social and economic reforms, political stability was achieved only in the early 20th century. However, military coups and juntas continued well into the mid-20th century. The authoritarian regime headed by Alberto Fujimori opened-up the economy and despite natural disasters and external economic impacts, the country is now receiving more foreign assistance and investments. While continued growth is likely, the matter of equity in the distribution of incomes across the country appears to remain as before. The rapid population growth in Lima is attributed mainly to rural-urban migration (DeSoto, H.1987 El Otro Sendaro, Lima)

\begin{tabular}{|c|l|r|}
\hline \multicolumn{3}{|c|}{ CITY POPULATIONS IN PERU (2013) } \\
\hline Rank & \multicolumn{1}{|c|}{ City } & \multicolumn{1}{c|}{ Population } \\
\hline 1 & Lima & $7,737,002$ \\
\hline 2 & Arequipa & 841,130 \\
\hline 3 & Callao & 813,264 \\
\hline 4 & Trujillo & 747,450 \\
\hline 5 & Chiclayo & 577,375 \\
\hline 6 & Iquitos & 437,620 \\
\hline 7 & Huancayo & 376,657 \\
\hline 8 & Piura & 325,466 \\
\hline 9 & Chimbote & 316,966 \\
\hline 10 & Cusco & 312,140 \\
\hline Source: & www.worldpopulationreview.com & \multicolumn{1}{|c|}{} \\
\cline { 1 - 2 } & \multicolumn{2}{|l|}{} \\
\cline { 1 - 2 } &
\end{tabular}

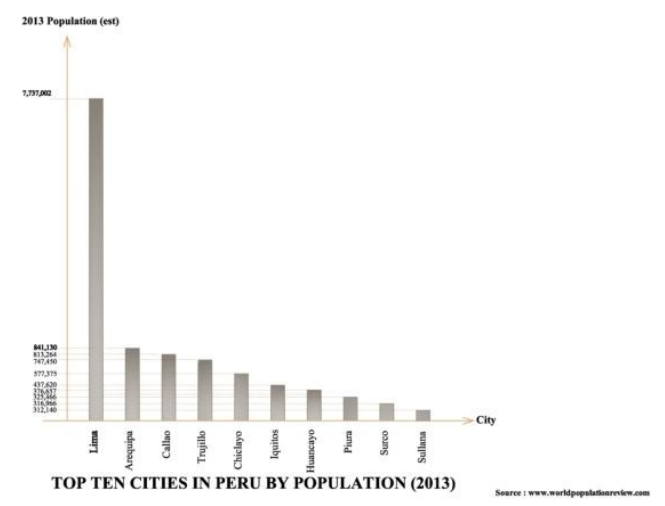

\section{Discussion}

One of the main intentions here in this paper was to examine the validity of Linsky's theoretical position noting that his conclusions were based on data only from one year, namely 1955 . Thus the sample of TWCs was eight in number selected here from among those small, predominantly agrarian coastal countries in the three continents of Asia, Africa and South America. The statistics were recent, being taken from 2010, 2011 and 2013. The countries selected included those that had undergone colonial subjugation by France (i.e.Vietnam and Senegal); Britain (i.e. Myanmar, Sri Lanka and Ghana); Portugal (i.e. Mozambique); and, Spain (i.e. Chile and Peru). The graphic presentations in Figures $1-$ 8 are based on the Tables $1-8$, respectively.

The conclusion that emerges from the analysis of data from all but one of the selected countries make is that 'Primacy' is a phenomena common to all of them. Even in the one apparent exception - the cities of Ghana - the pattern falls into line with the others if it is recognized that the first two ranked Ghanaian cities, Accra and Kumasi, underwent rapid infrastructure development together jointly as an interconnected dual system of cities particularly in the postcolonial era. Thus it may be concluded that the 'Theory of Primacy' is indeed validated.

Part and parcel of the validated theory is the assertion that the main causative factor behind the phenomena of primacy common to all these countries is a colonial economy that each of them have been subjected to. However, it may be observed that 'primacy' as a phenomena may be found in some countries 
that have not been under colonial subjugation. Examples in South Asia itself are Nepal and Bangladesh. Nepal was never subjected to European colonial occupation and Bangladesh was not a separate country during the pre-1947 period when it was part of British India. However, these two countries are clearly impacted by rapid urbanization and the two capital cities, Kathmandu and Dhaka, experience high rural-urban migration and also they clearly are 'primate' cities.

\section{Conclusions}

This present paper focused and expanded on one of the theories considered as being of fundamental relevance to the desired new spatial planning approach to deal with the multifarious problems arising from the rapid urbanization taking place in a large set of TWCs. It had to do with the phenomena of 'urban primacy' in its observable presence in and its relevance to the smaller Third World Countries (TWCs).

A few scholars had studied the relationship between the rank and size of cities within national city systems. Their studies suggested the existence of two distinct patterns. In one, rank and size are correlated in a regular and predictable manner. The other pattern is one in which the largest city predominates very substantially over the next in rank and all other cities. The latter pattern is said to display 'primacy' and the first ranking city is called a 'primate city'. Linsky in 1965 systematically pursued Jefferson's work that had been done three decades earlier. He surmised that the condition of 'primacy' is characteristic especially of the smaller "underdeveloped" countries in a transitional phase of social and economic development, having a colonial past, agricultural economies, low per capita incomes, high rates of population growth and being dependent upon exports. These are countries that have almost all undergone colonial subjugation and a notable point is the distortion in the spatial development of city systems that resulted from the prolonged imposition of colonial economies upon these countries.

An unavoidable question that then arises as to city systems so utterly distorted by the phenomena of primacy and their relevance to the respective post-colonial or other more recent development efforts within these TWCs. Surely it is clearly preferable that all these city systems themselves, regardless of the causative factors should be restructured so as to be able to provide an equitable distribution of social and economic infrastructure for the benefit of their respective hinterland populations; and, that doing so would greatly reduce rural-urban migration to these primate cities and thereby diminish the multitude of problems attendant upon rapid urbanization.

\section{REFERENCES}

Adarkwa, K.K. (2012). The Changing Face of Ghanaian Towns. African Review of Economics and Finance, (Vol. 4, No.1) Rhodes University, P.O. Box 94, Grahamstown, South Africa.

Gunaratna, L. (2014). Managing Urbanization in South Asia: Towards a Theoretical Base in Spatial Economics. Sri Lanka Economic Journal. (Vol. 13 No.2, Colombo)

Linsky, A.S. (1965) 'Some Generalization Concerning Primate Cities. Annals of the American Association of Geographers. (September: 506-513)

Miraftab, F. (2009). Insurgent Planning: Situating Radical Planning in the Global South. Planning Theory (8;32, Sage Publications, Los Angeles, London, New Delhi, Singapore)

Njero,P. http://www.ghanaweb.com/GhanaHomePage/geography/accra.php

http://reference.allrefer.com/encyclopedia/A/Accra.html 
Seto, K.C. et al (2012). Global Forecasts of Urban Expansion to 2030 and Direct Impacts on Biodiversity and Carbon Pools. Proceedings of the National Academy of Sciences (US) Available from: http://www.pnas.org/content/early/2012/09/11/1211658109.full.pdf+html> [10 October, 2013]

Vietnam Country Study (December 1987). Library of Congress Federal Research Division

Watson, V. (2012). Planning and the 'Stubborn Realities' of Global South Cities: Some Emerging Ideas. In: Planning Theory (online May 24 2012) DOI: 0.1177/1473095212446301 